\title{
THE ROLE OF PALEOLIMNOLOGY IN CLIMATE AND ENVIRONMENT RECONSTRUCTION AND LAKE RESTORATION IN LIGHT OF RESEARCH ON SELECTED BIOINDICATORS
}

\author{
Marta Wojewódka*, Dario Hruševar*** \\ ${ }^{*}$ Polish Academy of Sciences, Institute of Geological Sciences, Warsaw, Poland \\ ${ }^{* *}$ University of Zagreb, Faculty of Science, Zagreb, Croatia
}

corresponding author: Marta Wojewódka, e-mail: m.wojed@twarda.pan.pl

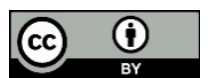

\begin{abstract}
Paleolimnologists and ecologists study biotic and abiotic variables to track long-term and short-term environment changes. Microscopic invertebrates, phytoplankton of freshwater ecosystems, and pollen grains have been extensively studied during the last decades. Surveys of modern and fossil biota composition might provide information about past changes caused by climate alteration and human activity. Furthermore, research on the modern population of these biological proxies may be utilized to assess environmental quality and restoration measures. This paper synthesizes knowledge of the use of selected microscopic invertebrates (Cladocera, Copepoda, Ostracoda, Rotifera), phytoplankton, and pollen grains for the aforementioned issues. This review shows that the ability of these biological proxies to indicate environment changes is versatile. Some of them may be utilized to track long-term changes of temperature (pollen) or $\mathrm{pH}$ (Diatomeae). Others are useful to reconstruct paleosalinity (Ostracoda) or conductivity (Ostracoda, Diatomeae), while the utilization of Rotifera and Copepoda in paleoreconstruction, due to the very poor preservation of the remains, is very limited, although these fauna are very useful for assessing modern water quality. Larger species of Cladocera are significant for lake restoration.
\end{abstract}

Keywords: Cladocera, Copepoda, Ostracoda, Rotifera, Diatomeae, pollen

\section{INTRODUCTION}

During the last century, environmental deterioration started to accelerate as an effect of anthropopressure and drastic climate change. One of the ecosystems suffering the most are freshwater bodies, which play a crucial role in many areas of human life and have been affected by humans in many different ways. These ecosystems are essential for biodiversity [1] and an important source of drinking water for some municipalities. It is thus essential to know the interplay between the abiotic and biotic elements of a given 
ecosystem and how these elements respond to alterations in the climate and environment. This knowledge would allow for better understanding of the current and possible future changes and the discovery of ways to prevent these changes, and it might be useful for the restoration of already degraded ecosystems.

One technique used to find out more about freshwater ecosystems is the use of biological proxies. Organisms tolerate a limited range of environmental variables such as physiochemical and biological conditions [2]. Hence, they can be used to assess environment quality and its short and long-term changes. In a freshwater ecosystem, microscopic invertebrates such as Rotifera, Cladocera, Copepoda, and Ostracoda have a particular role in the functioning of the ecosystem due to their pivotal position in the food chain. They are regarded as good indicators of environment changes because they quickly respond to environmental stressors [3 - 6]. Phytoplankton also reacts quickly to changes, and this may also provide valuable information about environmental alteration. Additionally, a greater perspective on changes in a particular catchment that have a direct effect on a given ecosystem (e.g., deforestation, erosion, agriculture) can be derived from pollen analysis.

The main aim of this paper is to summarize the abilities of particular microscopic invertebrates (Cladocera, Copepoda, Ostracoda, Rotifera), phytoplankton, and pollen grains to provide information that helps with the study of climate and environment changes as well as lake restoration. Part of this work is devoted to the use of these organisms to trace environmental changes, in particular climate alteration. The implementation of particular biological proxies for reconstructing given variables found in the literature is discussed. The remaining portion of this work looks into the adaptation of the paleolimnological and ecological traits of those proxies during the lake recovery process.
To accomplish the goal of this work authors explored the Science Direct database of journals, articles and books. Key words were used to find articles dealing with aforementioned issues. Based on gathered literature, proportions of the used biological proxies in studies of paleo-reconstruction and lake restoration are displayed on the Figure 1. Further, indication abilities of given biological proxies in paleo- and limnology are summarized in the Table 1.

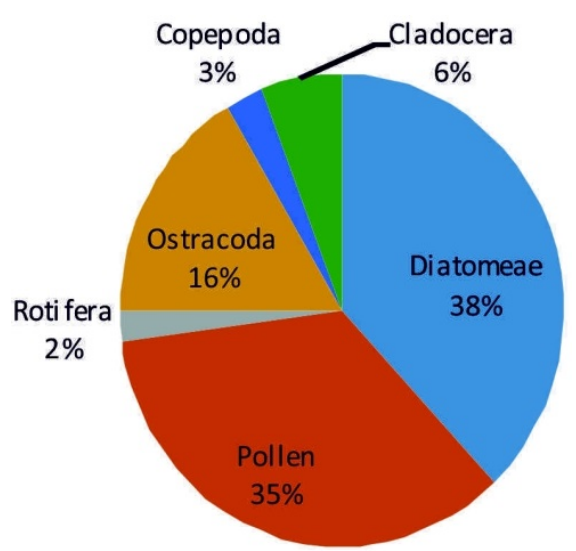

a)

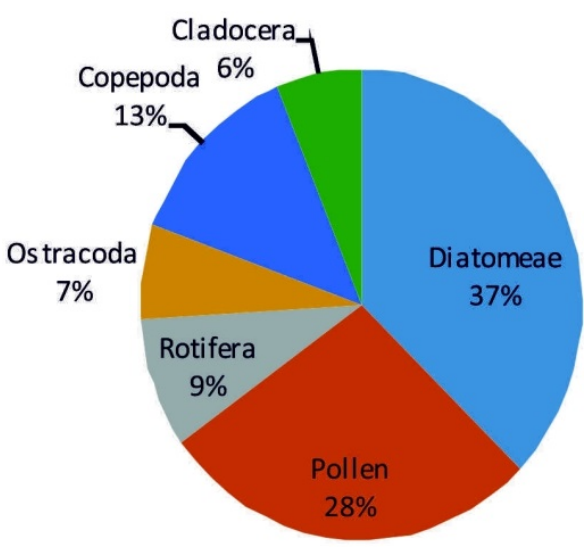

b)

Figure 1. Proportions of the used given biological proxies in: a) paleo-reconstruction of climate and environment changes, b) lake restoration 
Table 1. Comparison of indication abilities of selected biological proxies in the paleolimnological (S - sediments) and limnological studies (W - water) (++ very good indicator, + moderately good indicator, = low indication abilities, but sometimes might provide useful qualitative information, $\mathrm{n} / \mathrm{a}$ not applicable) [7 - 15 and other articles listed for each paragraphs respectively]

\begin{tabular}{|c|c|c|c|c|c|c|c|c|c|c|c|c|}
\hline \multirow{2}{*}{$\begin{array}{c}\text { Inferred } \\
\text { variables }\end{array}$} & \multicolumn{2}{|c|}{ Pollen } & \multicolumn{2}{|c|}{ Diatomeae } & \multicolumn{2}{c|}{ Rotifera } & \multicolumn{2}{|c|}{ Cladocera } & \multicolumn{2}{c|}{ Ostracoda } & \multicolumn{2}{c|}{ Copepoda } \\
\cline { 2 - 16 } & $\mathrm{S}$ & $\mathrm{W}$ & $\mathrm{S}$ & $\mathrm{W}$ & $\mathrm{S}$ & $\mathrm{W}$ & $\mathrm{S}$ & $\mathrm{W}$ & $\mathrm{S}$ & $\mathrm{W}$ & $\mathrm{S}$ & $\mathrm{W}$ \\
\hline Temperature & ++ & $\mathrm{n} / \mathrm{a}$ & $=$ & $=$ & & $=$ & + & $=$ & ++ & $=$ & & + \\
\hline Humidity & ++ & $\mathrm{n} / \mathrm{a}$ & + & & & & + & & + & & & \\
\hline Water level & $=$ & $\mathrm{n} / \mathrm{a}$ & + & $=$ & & & ++ & $=$ & + & & & $=$ \\
\hline Trophic status & & $\mathrm{n} / \mathrm{a}$ & ++ & ++ & ++ & ++ & ++ & ++ & $=$ & $=$ & ++ & ++ \\
\hline $\mathrm{pH}$ & & $\mathrm{n} / \mathrm{a}$ & ++ & ++ & & $=$ & + & + & $=$ & ++ & & + \\
\hline Salinity & & $\mathrm{n} / \mathrm{a}$ & ++ & ++ & & $=$ & $=$ & $=$ & ++ & ++ & & + \\
\hline Conductivity & & $\mathrm{n} / \mathrm{a}$ & ++ & ++ & & $=$ & $=$ & $=$ & ++ & + & & + \\
\hline
\end{tabular}

\section{MICROSCOPIC INVERTEBRATES, PHYTOPLANKTON AND POLLEN AS INDICATORS OF CLIMATE AND ENVIRONMENTAL CHANGES}

Climate changes lead to the alteration of abiotic conditions, which in turn directly affects biota populations [16]. The response of organisms to climate changes is manifested by changes in geographic distribution, species composition and their abundance [16, 17]. Because of a strong relationship between fauna, flora, and climate, the identification of some past invertebrate communities and alteration in vegetation may allow us to gain knowledge of past climate conditions. The biological proxies may be used to estimate qualitative or quantitative paleoclimate and paleo-environment conditions based on animal remains and/or pollen grains stored in lake sediments. The qualitative reconstruction provides subjective information on what the obtained data from proxies represents, e.g., warmer or cooler conditions [18]. The second type of paleo-reconstruction encompasses a method of quantifying variables. This technique requires the creation of what is known as a training set (or a modern calibration set). This calibration set includes information about the composition and abundance of modern species in conjunction with modern environmental parameters. Further, the set is applied in the numerical modelling of the relationship between species assemblage and environmental variables. The obtained interference model (or transfer function) is applied for the quantitative reconstruction of climatic and environmental parameters through time [19].

\section{Some microscopic invertebrates and elements of phytoplankton}

Climatic alteration recorded at high resolution or the detection of abrupt and short climate changes could be studied using invertebrate analysis. Many studies have used microscopic invertebrates for climate reconstruction. Most of them have shown a relative alteration of climate and environment and have confirmed that microscopic invertebrates and phytoplankton are reliable reconstruction tools. 


\section{Temperature}

The primarily climatic parameter that significantly influences biotic and abiotic factors is temperature. For exact temperature determination, Cladocera is a rather poor indicator (with several exceptions). There are some species regarded as cold-tolerant ones (e.g. Alona affinis), but temperature is not a factor determining their presence. Therefore, they cannot be used independently as indicators of temperature. Nonetheless, measurements of the diversity in the Cladocera species may somewhat suggest climate alteration. A significant shift in Cladocera assemblages, from poor into more diverse ones, is observed at the border between the cold period (Late Glacial) and the Holocene $[3,20]$. What is more, there are significant shifts in Cladocera assemblages along the altitude gradient [21]. Recently, progress in the development of Cladocera-inferred temperature reconstruction has also been made. Lotter et al. [22] developed the first temperature transfer function based on Cladocera assemblages recorded in alpine lakes, which was further successfully applied on sediment core from Lake Gerzensee, Switzerland [23]. Another example of successful Cladocera-based temperature reconstruction is a work by Korhola et al. [24] for Northern Fennoscandia. In spite of that, data from water fleas to be used for temperature reconstruction needs to be interpreted carefully. Additionally, within the Ostracoda group many species have specific water temperature requirements $[4,5]$. However, Ostracoda were sporadically applied in temperature reconstruction [25]. In terms of phytoplankton, the most useful and common organisms in paleolimnological surveys are Diatomeae. However, their utilization in reconstructing past temperature is rather questionable [26]. It is generally argued that the diversity of Diatomeae may be more dependent on other variables (trophy state, $\mathrm{pH}$, conductivity) that are indirectly linked to climate variability rather than temperature [27].

\section{Water level changes}

Despite the limited application of the aforementioned microscopic invertebrates in tracing direct climate alteration, they are invaluable in indirect reconstructions. Cladocera, Ostracoda and Diatomeae prove themselves as essential proxies of water level changes, which is critical in the reconstruction of past climate. Wet periods are usually marked by an increase of water level, while more dry ones are usually characterized by a drop in lake water level [28]. Relative water level changes may be assessed based upon the ratio of planktonic/littoral Cladocera species [29] or planktonic/tychoplanktonic and benthic Diatomeae taxa [28].

The discussed biological indicators also allow for an insight into quantitative water level fluctuations. For this purpose, an intralake or large regional training set must be applied. This can be seen in a work by Nevalainen and Luoto [30], who tested an intralake training set of Cladocera to trace paleohydrology in Lake Pieni-Kauro (Finland). Korhola et al. [24, 31] verified the usefulness of the regional Cladocera training set in the reconstruction of lake level changes and showed how Cladocera may be used for this purpose. In the case of Ostracoda, some general patterns are established, but it is quite difficult to depict statistical relationships between water depth and the Ostracoda community. There are some species correlated with shallow (Darwinula stevensoni) or deep water phases (Cypria ophthalmica) $[4,5]$. The relationship between Ostracoda and water level has been used to identify shallow and deep lake stages by, e.g., Wrozyna et al. [32] and Alivernini et al. [33]. What is more, creation of intralake transfer function for Ostracoda may let to obtain the qualitative reconstruction of water level as was proved by Wrozyna et al. [34] for lake Nam Co (China). Quantitative diatom-based lake level reconstructions are rather scarce [28]. 
pH value

The discussed microscopic elements have given some researchers insight into past climate oscillations indirectly by following such variables as $\mathrm{pH}$, conductivity, salinity, and so on. Many studies highlight a clear relationship between Cladocera and $\mathrm{pH}$, especially in terms of acidification. There is a general pattern that the decline of $\mathrm{pH}$ usually occurs simultaneously with a decrease in species diversity [3]. This latter trait is in conjunction with acid-tolerate species, e.g., Alonella exigua [35], which may enable $\mathrm{pH}$ changes to be qualitatively determined. Diatomeae are regarded as very good indicators of $\mathrm{pH}$ [36] and have been broadly used in climate and environmental reconstruction worldwide [37]. Due to their high sensibility, this algae group is useful in quantitative $\mathrm{pH}$ reconstruction. An example of a successful reconstruction of $\mathrm{pH}$ history is the research by Renberg and Hellberg [38], which studies three Swedish lakes spanning the whole Holocene.

\section{Salinity and conductivity}

Additionally, the discussed group of organisms may be utilized to reconstruct changes of salinity, conductivity, or trophy state due to their sensitivity to physico-chemical water parameters. Salinity and conductivity significantly affect the abundance and species diversity of Ostracoda [4]. There are numerous indicative species with habitat requirements varying from hypersaline to freshwater ones [5]. These features may be implemented in retrieving salinity and/or conductivity, even in a fully quantitative model [e.g., 39]. The quantification of conductivity and salinity is also possible based on data from Diatomeae $[40,41]$.

\section{Trophy state}

An increase in water temperature may trigger the enhancement of trophy state. Therefore, some information can be derived from the reconstruction of nutrient input. Trophy state may be well indicated by Cladocera and Diatomeae [3, 4]. Some Ostracoda taxa are also sensitive to concentration of nutrients [5].

Cladocera are usually used to infer qualitative changes of trophy state. The structure of Cladocera communities significantly varies with alterations in nutrient state. There is a general assumption that an increase in the contribution of Bosmina longirostris is due to a higher trophy state. However, the most useful information can be derived from an observation of alterations within the whole community. Some attempts have been made to track qualitative changes of total phosphorus (TP) based on water fleas [42]. It was possible due to a strong correlation between Cladocera assemblages and TP in a regional training set. This kind of reconstruction is not frequent and to conduct one, one must know the regional relationship between species composition and the environmental variables driving their distribution. To get accurate quantitative reconstruction, Diatomeae may be involved. This algal group is well known as a powerful tool for reconstruction of nutrient, especially phosphorus loading [43].

The adaptation of Copepoda or Rotifera for paleoreconstruction is rather questionable due to the weak preservation of their remains in lake sediments $[44,45]$ and because they are often lost during sediment preparation. Another reason might be the lack of guides to identification and thus small interest, as reflected by the number of paleolimnological studies that use those organisms (Figure 1). The remains of these animals most likely to be found in fossil records are spermatophores (Copepoda) [44] and eggs sacks (Copepoda, Rotifera) [45]. Fossil Rotifera are hardly ever found in lake sediment. One of the exceptions is the sediment core from Lake Crawford (Canada), where numerous fossil remains were preserved. Analysis of them aided the tracing of eutrophication [46]. Due to the great importance of Diatomeae in lake-based reconstruction, other algae groups are neglected in this paper. It is, however, noteworthy that such algae as Chlorophyta, 
Pediastrum, or Cyanobacteria might be also useful as proxies of environmental alteration, especially those that link to eutrophication [47, 48].

\section{Pollen grains}

One of the principal techniques of paleoclimatic reconstruction is analysis of pollen grains (palynology) from terrestrial and water plants stored in lake sediments. There are hundreds of palynological data from different regions of the world that encompass varying time and space scales but commonly spanning the Holocene (the last ca. $11700 \mathrm{yr}$ before $\mathrm{AD}$ 2000) [49]. Historically, the character of the pollen record itself has been applied in chronostratigraphy [50]. Many studies have given insight into the sequence of vegetation changes during the last interglacialglacial cycle. Most of them provide information about relative changes. For instance, a shift from Pinus to Picea may be interpreted as an alteration from cold to slightly warmer and more wet conditions [51], just as the Fagus-Carpinus signature of the Subatlantic describes a more humid and colder environment compared to the climate of the Atlantic [52]. On the other hand, primary and secondary pollen anthropogenic indicators provide useful information about direct/indirect human impact on environment.

The quantification of pollen data and its interpretation is sometimes problematic due to the different rate of pollen production and dispersal (anemophilous vs. zoophilous plants). The preservation potential of pollen grains is closely related to the share of sporopollenin through the pollen wall. The sporopollenin preservation, in turn, is depended on abiotic factors, as $\mathrm{pH}$ or Eh. Despite some difficulties, numerous quantitative records of past temperature have been found. For example, Seppä and Birks [53] reconstructed changes of summer temperature and precipitation through the Holocene at Lake Tsuolbmajavri (Finland). It is, however, noteworthy that pollen analysis does not seem to be adequate to track short and sudden climate changes [54] due to a time lag in response of vegetation to climate changes. In such a case, other biological proxies are more appropriate.

The most frequently used in paleolimnological research are Diatomeae and pollen (Figure 1). Further, Ostracoda have been used to reconstruct climate and environmental changes (Figure 1). Due to the different indication ability of given variables (Table 1), it is necessary to combine analysis of one biological proxy with another or with abiotic variables.

\section{MICROSCOPIC INVERTEBRATES, PHYTOPLANKTON AND POLLEN IN THE LAKE/RIVER CATCHMENT AREA RESTORATION}

\section{Paleolimnological traits of fauna and flora in lake restoration}

Lake restoration is quite a broad term and usually refers to all techniques leading to the recovery of natural or semi-natural conditions prevailing in a given lake before human disturbance [55]. For successful lake restoration, it is critical to determine reference conditions - the so-called baseline. For that purpose, historical data from environmental monitoring are usually used. The related time scale is either limited or even unavailable. Here, the paleolimnology approach may come in handy due to its ability to track long-term changes by using the biological indicators discussed above. Paleolimnological surveys can also aid the determination of parameters that need to be considered in lake management [56].

Antrophogenic disturbance of lakes includes acidification, water level changes, and toxic metal pollution [57]. However, one of the most serious issues that lake management decisionmakers need to tackle is the widespread eutrophication of freshwater ecosystems. This phenomenon is especially problematic as it leads to cyanobacteria blooms, a decrease of 
biodiversity, water turbidity [55], and impairment in using these water bodies for socio-economic goals. Therefore, it is necessary to recover already degraded lakes. However, one question must be answered herein: what are the reference conditions for the restoration target? Quantitative techniques using biological indicators could allow this question to be answered and could determine a magnitude of changes. The potential of Diatomeae in the assessment of background conditions and restoration targets has been broadly recognized and applied [58]. The possibility of quantifying nutrient alteration makes Diatomeae especially useful for that purpose. Their analysis is one of the most frequent tools being applied within the paleolimnological approach towards lake restoration.

The paleolimnological technique can also be applied to determine the background conditions for acidity, organic carbon concentration, or variation in trace metal content [57]. Diatomeae may, again, be helpful here, as they can be used to quantitatively assess changes of acidification (reflected by $\mathrm{pH})$.

There are some paleolimnological approaches implemented in lake restoration. One of them characterizes the past habitat of a specific species community [57]. This may be exemplified by Cladocera-based analysis used to reconstruct the density of a past fish community [59]. On the other hand, analysis of pollen grains or plant fragments (e.g. the leaf spinule of Ceratophyllum or the basal hair cells of Nymphaeaceae) provide information on the alteration of species richness and the spatial diversity of submerged marcrophytes $[60,61]$.

The development of a proper restoration strategy requires tools for diagnosing water quality. It must also address the question of how given ecosystems behave under changing environmental parameters nowadays. For obvious reasons, bioindicator analyses (paleoand limnological) are broadly used methods.

\section{Selected microscopic invertebrates and elements of phytoplankton as powerful tool to find appropriate way of lake restoration}

Nutrient overload in a freshwater ecosystem leads to numerous transformations. It triggers an increase of fish biomass, including species that feed at the bottom and those preferring zooplankton as a food. This, in turn, leads to water turbidity (due to sediment resuspension) and a decline in microscopic invertebrates feeding on phytoplankton $[55,62]$. Therefore, microscopic invertebrates play a crucial role in controlling algal bloom. Consequently, an increase of phytoplankton biomass finally causes a decrease of water transparency and oxygen depletion. Progressive eutrophication further leads to a decline in Rotifera, Cladocera, and Copepoda, and - in extreme situations - the disappearance of fish [63]. All of these interplays within the trophy structure are utilized in a restoration technique called biomanipulation. Fish removal is a broadly used method that significantly affects water quality in eutrophicated lakes. This method is based on what are known as the mechanisms of top-down control. Thus, removing higherlevel consumers (e.g. fish) from the food web structure will cause cascade effects by increasing the zooplankton biomass [64] and consequently decreasing the algal abundance. A great role in food web manipulation is played by large Cladocera species, especially those from the Daphniidae family [65]. It is generally assumed that big Cladocera species are more efficient filters than other zooplankton organisms [66]. Hence, the role of other microscopic invertebrates is often neglected. However, small Rotifera, Cladocera, or Copepoda are important components of the food web structure in freshwater ecosystems [67]. As such, they may significantly contribute to the process of algal reduction as well. In some cases of Mazurian lakes (Poland), small Cladocera, detritophagous Rotifera, and Copepoda had a significant role in controlling algal biomass [68]. Therefore, there was some discussion as to whether small zooplankton can fulfill the same function as larger Cladocera. It was shown that their appropriate biomass is 
essential [68]. The ability of Ostracoda to control algal biomass, especially benthic green algal, was confirmed as well [69]. Thus, this group could sometimes be suitable in biomanipulation [70]. But, Daphnia species do still seem to be the most efficient organisms in filtering water $[71,72]$.

Submerged macrophytes are important in the modeling of freshwater ecosystems [73] and have an impact on both trophy state and water clarity [59, 74]. Aquatic vegetation provides food resources and harbor for many microscopic invertebrates [62, 75]. The structure and density of submerged vegetation have a direct influence on species composition, mutual biotic interactions, and of physico-chemical water variables [67]. Therefore, the re-establishment of macrophytes is used as a biological method in lake restoration. The active contribution of submerged vegetation in combating eutrophication is linked with several processes, including providing refuge for zooplankton [76]. Therefore, the proper architecture of the structure of macrophytes is key here because the heterogeneity, spatial distribution, and morphology of aquatic plants directly determine the size, composition, and density of microscopic invertebrates [77]. A significant correlation of Diatomeae with type of aquatic plants has also been found [78]. Thus, analysis of composition and density of zooplankton and phytoplankton may be useful to evaluate potential direction in lake management and restoration as achieved by the use of macrophytes manipulation [65, 78]. Furthermore, the density and structure of microscopic invertebrate communities is prone to change along with nutrient gradient. It may thus be useful to decide if top-down and bottom-up (physical and chemical methods for reducing nutrient availability) controls are important [72,79]. Especially sensitive and powerful for assessing the necessity of some trophy control mechanisms are Rotifera because they strongly react to trophy state alteration [6]. Due to that, and as fish put smaller pressure on those organisms than on large Cladocera, Rotifera might also act as a great indicator of bottom-up processes [79]. In general, an increase of nutrient content leads to an increase in abundance of Rotifera and a decline in their diversity [6]. Information about species composition and their abundance may be applied in the formation of the rotifer trophic state index $\left(\mathrm{TSI}_{\mathrm{ROT}}\right)$, which is used to determine trophy state [80]. The response of the zooplankton community to nutrient enrichment may also be reflected by (1) a shift within the Cladocera community (an increase in the contribution of smaller taxa) and a decline of species richness, (2) a higher share of Cyclopoida (Copepoda) and a decline or even disappearance of Calanoids (Copepoda), and (3) an increase of zooplankton biomass $[71,72,81]$. Considering the above, Rotifera, Cladocera, and Copepoda may be handy in the creation of a restoration concept, for monitoring water quality during restoration, and for assessing the effectiveness of the restoration.

According to the Science Direct database, Diatomeae and pollen were the most frequent biological proxies in lake restoration (Figure 1b). In spite of that, all discussed groups of organisms can significantly contribute to lake restoration. A big advantage of using zooplankton to assess water quality is indisputably its cost-efficiency [72].

\section{CONCLUSION}

The presented synthesis of the ability of some microscopic invertebrates, phytoplankton, and pollen grains to indicate environment changes displays their versatile utilization. They are tools suitable for tracking long-term and shortterm changes. They may be helpful in applied ecology. However, some limitations in using the given bioindicators do exist. To quantitatively follow long-term temperature changes, pollen analysis is a powerful tool. Information about the zooplankton and phytoplankton communities make it possible to trace water level changes (especially when using Cladocera and Diatomeae), $\mathrm{pH}$ (even quantitatively, when using Diatomeae), conductivity (especially by using Diatomeae 
and Ostracoda), salinity (when using Ostracoda), or the trophy state. The paleolimnological approach uses these organisms in lake restoration, i.e., to determine background conditions, but also to indicate a potential way of restoration. Furthermore, the organisms listed are crucial in active restoration (especially large Cladocera) because of their interplays with physicochemical variables and other biota of freshwater ecosystems. Finally, zooplankton reflects changes in lower and higher trophy states and environmental quality due to its pivotal position in the food chain of freshwater ecosystems. Therefore, zooplankton can be applied to assess restoration measures and environment state.

\section{REFERENCES}

[1] D.L. Strayer, D. Dudgeon, Freshwater Biodiversity Conservation: Recent Progress and Future Challenges, Journal of the North American Benthological Society 29(2010) 1, 344-358.

[2] E.A. Holt, S.W. Miller. Bioindicators: Using Organisms to Measure Environmental Impacts, Nature Education Knowledge 3(2010) 10, 8-13.

[3] A. Korhola, M. Rautio, Cladocera and other Branchiopod crustaceans, Tracking environmental change using lake sediments, ed. J.P. Smol, J.B. Birks, W.M. Last, Springer, Dordrecht, Heidelberg, New York, London, 2001.

[4] J.A. Holmes, Ostracoda, Tracking environmental change using lake sediments, ed. J.P. Smol, J.B. Birks, W.M. Last, Springer, Dordrecht, Heidelberg, New York, London. 2001.

[5] F. Ruiz, M. Abad, A.M. Bodergat, P. Carbonel, J. Rodríguez-Lázaro, M.L. González-Regalado, A. Toscano, E.X. García, J. Prenda, Freshwater ostracods as environmental tracers, International Journal of Environmental Science and Technology 10(2013) 5, 1115-1128.

[6] M. Špoljar, Microaquatic communities as indicators of environmental changes in lake ecosystems, Journal of Engineering Research 1(2013) 1, 29-42.

[7] J. Półtoracka, Współczynniki fitoplanktonowe jako metoda określania stopnia troficzności środowisk wodnych, Ekologia Polska Seria B XV (1969) 4, 112-119.

[8] D.N. Saksena, Rotifers as Indicators of Water Quality, Acta hydrochimica et hydrobiologica 15(1987) 5, 481-485.

[9] O. Külköylüoğlu, On the usage of ostracods (Crustacea) as bioindicator species in different aquatic habitats in the Bolu region, Turkey, Ecological Indicators 4(2004) 2, 139-147.

[10] J. Larsen, H.J.B. Birks, G. Raddum, A. Fjellheim, Quantitative relationships of invertebrates to $\mathrm{pH}$ in Norwegian river systems, Hydrobiologia 328(1996) 1, 57-74.

[11] R.L. Wallace, H.A. Uyhelji, Rotifera, Encyclopedia of Inland Waters, ed. G.E. Likens, Elsevier, Oxford, 2009.

[12] M. Gophen, Seasonal rotifer dynamics in the long-term (1969-2002) record from Lake Kinneret (Israel), Hydrobiologia 546(2005) 1, 443-450.

[13] I.F. Baruta, A. Nazik, N. Balkıs, A. Aksua, M.S. Erşan, Ostracoda as bioindicators of anthropogenic impact in salt lakes, salt pans, and a lagoon: A case study from the Gulf of Saros coast (NE Aegean Sea), Turkey, Revue de micropaléontologie 58(2015) 4, 351367.

[14] T.E. Andrew, J.A.M. Andrew, Seasonality of rotifers and temperature in Lough Neagh, N. Ireland, Hydrobiologia 546(2005) 1, 451-455.

[15] J.W. Reid, C.E. Williamson, Copepoda, Ecology and Classification of North American Freshwater Invertebrates, ed. G.E. Likens, Elsevier Science, Amsterdam, USA, UK, 2009.

[16] C.M. Prather, S.L. Pelini, A. Laws, E. Rivest, M. Woltz, C.P. Bloch, I. Del Toro, C.K. Ho, J. Kominoski, T.A. Newbold, S. Parsons, A. Joern, Invertebrates, ecosystem services and climate change, Biological Reviews 88(2013), 327-348. 
[17] S. Brewer, J. Guiot, D. Barboni, Pollen methods and studies, Encyclopedia of Quaternary Science, ed. S.A. Elias, Elsevier Science, Amsterdam, USA, UK, 2007.

[18] R. Bradley, 1 Paleoclimatic reconstruction, International Geophysics 68(1999), 1-10.

[19] S. Brewer, J. Guiot, D. Barboni, Encyclopedia of Quaternary Science, ed. S.A. Elias, Elsevier Science, Amsterdam, USA, UK, 2007, 2497-2508.

[20] K. Szeroczyńska, A. Tatur, J. Weckstrom, M. Gąsiorowski, A.M. Noryśkiewicz, E. Sienkiewicz, Holocene environmental history in northwest Finnish Lapland reflected in the multiproxy record of a small subarctic lake, Journal of Paleolimnology 38(2007) 1, 25-47.

[21] J. Green, Altitudinal distribution of tropical planktonic Cladocera, Hydrobiologia 307(1995) 1-3, 75-84.

[22] A.F. Lotter, H.J.B. Birks, W. Hofmann, A. Marchetto, Modern diatom, cladocera, chironomid, and chrysophyte cyst assemblages as quantitative indicators for the reconstruction of past environmental conditions in the Alps. I. Climate, Journal of Paleolimnology 18(1997) 4, 395-420.

[23] A.F. Lotter, H.J.B. Birks, U. Eicher, W. Hofmann, J. Schwander, L. Wick, Younger Dryas and Allerød summer temperatures at Gerzensee (Switzerland) inferred from fossil pollen and cladoceran assemblages, Palaeogeography Palaeoclimatology Palaeoecology 159(2000) 3-4, 349-361.

[24] A. Korhola, H. Olander, T. Blom, Cladoceran and chironomid assemblages as qualitative indicators of water depth in subarctic Fennoscandian lakes, Journal of Paleolimnology 24(2000) 1, 43-54.

[25] D.L. Delorme, S.C. Zoltai, L.L. Kalas, Freshwater shelled invertebrate indicators of paleoclimate in northwestern Canada during late glacial times, Canadian Journal of Earth Sciences 14(1977) 9, 2029-2046.
[26] A.W. Mackay, V.J. Jones, R.W. Battarbee, Approaches to Holocene climate reconstruction using diatoms, Global change in Holocene, ed. A.W. Mackay, H.J.B. Birks, R.W. Battarbee, F. Oldfield, Hodder Arnold, London, 2003.

[27] N.J. Anderson, Miniview: Diatoms, temperature and climatic change, European Journal of Phycology 35(2000) 4, 307-314.

[28] J.A. Wolin, J.R. Stone, Diatoms as indicators of water-level change in freshwater lakes, The Diatoms Applications to the Environmental and Earth Sciences, ed. E.F. Stoermer, J.P. Smol, Cambridge University Press, UK, 2010.

[29] K. Szeroczyńska, Palaeolimnological investigations in Poland based on Cladocera (Crustacea), Palaeogeography, Palaeoclimatology, Palaeoecology 140(1998) 1-4, 335-345.

[30] L. Nevalainen, T.P. Luoto, Intralake training set of fossil Cladocera for paleohydrological interefences: evidence for multicentennial drought during the Medieval Climate Anomaly, Ecohydrology 5(2012) 6, 834-840.

[31] A. Korhola, M. Tikkanen, J. Weckström, Quantification of Holocene lake-level changes in Finnish Lapland using a cladocera - lake depth transfer model, Journal of Paleolimnology 34(2005) 2, 175-190.

[32] C. Wrozyna, P. Frenzel, G. Daut, R. Mäusbacher, L. Zhu, A. Schwalb, Holocene Lake-Level Changes of Lake Nam Co, Tibetan Plateau, Deduced from Ostracod Assemblages and $\delta 180$ and $\delta 13 \mathrm{C}$ Signatures of Their Valves, Developments in Quaternary Science 17(2012), 281-295.

[33] M. Alivernini, L.G. Akita, M. Ahlborn, N. Borner, T. Haberzettl, T. Kasper, B. Plessen, P. Peng, A. Schwalb, J. Wang, P. Frenzel, Ostracod-based reconstruction of Late Quaternary lake level changes within the Tangra Yumco lake system (southern Tibetan Plateau), Journal of Quaternary Science 33(2018) 6, 713720. 
[34] C. Wrozyna, P. Frenzel, P. Steeb, L. Zhu, A. Schwalb, Recent lacustrine Ostracoda and a first transfer function for palaeowater depth estimation in Nam Co, southern Tibetan Plateau, Revista Española de Micropaleontología 41(2009) 1-2, 1-20.

[35] E. Zawisza, I. Zawiska, A. CorreaMetrio, Cladocera community composition as a function of physicochemical and morphological parameters of dystrophic lakes in $\mathrm{NE}$ Poland, Wetlands 36(2016) 6, 11311142.

[36] H.J.B. Birks, J.M. Line, S. Juggins, A.C. Stevenson, C.J.F. ter Braak, Diatoms and $\mathrm{pH} \quad$ Reconstruction, Philosophical Transactions of The Royal Society B: Biological Sciences 327(1990), 263278.

[37] Ch. Bigler, R.I. Hall, Diatoms as quantitative indicators of July temperature: A validation attempt at century-scale with meteorological data from northern Sweden, Palaeogeography, Palaeoclimatology, Palaeoecology 189(2003) 3-4, 147-160.

[38] I. Renberg, T. Hellberg, The $\mathrm{pH}$ history of lakes in southwestern Sweden, as calculated from the sub-fossil diatom flora of the sediments, Ambio A Journal of the Human Environment 11(1982) 1, 30-33.

[39] J. Ramón-Mercau, C. Laprida, An ostracod-based calibration function for electrical conductivity reconstruction in lacustrine environments in Patagonia, Southern South America, Ecological Indicators 69(2016), 522-532.

[40] D. Verschuren, K.R. Laird, B.F. Cumming, Rainfall and drought in equatorial east Africa during the past 1,100 years, Nature 403(2000), 410-414.

[41] K.R. Laird, S.C. Fritz, B.F. Cumming, A diatom-based reconstruction of drought intensity, duration, and frequency from Moon Lake, North Dakota: a subdecadal record of the last 2300 years, Journal of Paleolimnology 19(1998) 2, 161-179.

[42] A.E. Lotter, H.J.B. Birks, W. Hofmann,
A. Marchetto, Modern diatom, cladocera, chironomid, and chrysophyte cyst assemblages as quantitative indicators for the reconstruction of past environmental conditions in the Alps. II. Nutrients, Journal of Paleolimnology 19(1998) 4, 443-463.

[43] R.I. Hall, J.P. Smol, A Weightedaveraging Regression and Calibration Model for Inferring Total Phosphorus Concentration from Diatoms in British Columbia (Canada) Lakes, Freshwater Biology 27(1992), 417-434.

[44] D.G. Frey, Remains of animals in Quaternary lake and bog sediments and their interpretation, Advances in Limnology 2(1964), 1-114.

[45] O. Bennike, Fossil egg sacs of Diaptomus (Crustacea: Copepoda) in Late Quaternary lake sediments, Journal of Paleolimnology 19(1998) 1, 77-79.

[46] C.L. Turton, J. McAndrews, Rotifer loricas in second millennium sediment of Crawford Lake, Ontario, Canada, Review of Palaeobotany and Palynology, 141(2006) 1, 1-6.

[47] E.J. Cook , B. van Geel, S. van der Kaars, J. van Arkel, A review of the use of non-pollen palynomorphs in palaeoecology with examples from Australia, Palynology 35(2011) 2, 155178.

[48] O. Volik, F.M.G. McCarthy, N. L. Riddick, Insights from pollen, nonpollen palynomorphs and testate amoebae into the evolution of Lake Simcoe, Journal of Paleolimnology 56(2016) 2-3, 137-152.

[49] http://www.stratigraphy.org/ Accessed: June 7, 2019.

[50] H. Seppä, Pollen analysis, principles, The Encyclopedia of Quaternary Science 3, ed. S.A. Elias, Elsevier, Amsterdam, 2013.

[51] R. Schmidt, N. Pugliese, J. Muller, K. Szeroczyńska, D. Bogner, R. Melis, C. Kamenik, A. Baric, D. Danielopol, Palaeoclimate, vegetation and coastal lake development, from upper pleniglacial until early Holocene, in the northern Adriatic Valun Bay (Isle of 
Cres, Croatia), II Quaternario 14(2001) $1,61-78$.

[52] A. Traverse, Paleopalynology $-2^{\text {nd }}$ edition, Springer, Dordrecht, 2007.

[53] H. Seppä, H.J.B. Birks, July mean temperature and annual precipitation trends during the Holocene in the Fennoscandian tree-line area: pollenbased climate reconstructions, The Holocene 11(2001) 5, 527-539.

[54] R. Bradley, 9 Pollen analysis, International Geophysics 68(1999), 357396.

[55] M. Søndergaard, E. Jeppesen, H.S. Jensen, Encyclopedia of Lakes and Reservoirs. Encyclopedia of Earth Sciences Series, ed. L. Bengtsson, R.W. Herschy, R.W. Fairbridge, Springer, Dordrecht, 2012, 455-458.

[56] I. Larocque-Tobler, Editorial: Using Paleolimnology for Management and Restoration of Lakes, Frontiers in Ecology and Evolution 4(2016), 5-6.

[57] H. Bennion, R.W. Battarbee, C.D. Sayer, G.L. Simpson, T.A. Davidson, Defining reference conditions and restoration targets for lake ecosystems using palaeolimnology: a synthesis, Journal of Paleolimnology 45(2011) 4, 533-544.

[58] H. Bennion, G.L. Simpson, B.J. Goldsmith, Assessing degradation and recovery pathways in lakes impacted by eutrophication using the sediment record, Frontiers in Ecology and Evolution 3(2015), 94.

[59] E. Jeppesen, P. Leavitt, L. de Meester, J. Peder, Functional ecology and palaeolimnology: using cladoceran remains to reconstruct anthropogenic impact, Jensen Trends in Ecology \& Evolution 16(2001) 4, 191-198.

[60] D. Demske, P.E. Tarasov, T. Nakagawa, Suigetsu 2006 Project Members, Atlas of pollen, spores and further non-pollen palynomorphs recorded in the glacial interglacial late Quaternary sediments of Lake Suigetsu, central Japan, Quaternary International 290-291(2012), 164-238.

[61] J. Salgado, C. Sayer, L. Carvalho, T. Davidson, I. Gunn, Assessing aquatic macrophyte community change through the integration of paleolimnology and historical data at Loch Leven, Scotland, Journal of Paleolimnology 43(2010) 1, 191-204.

[62] M. Špoljar, T. Tomljanović, T. Dražina, J. Lajtner, H. Štulec, D. Matulić, J. Fressl, Zooplankton structure in two interconnected ponds: similarities and differences, Croatian Journal of Fisheries 74(2016) 1, 6-13.

[63] H.W. Paerl, T.G. Otten, Harmful cyanobacterial blooms: causes, consequences, and controls, Microbial Ecology 65(2013) 4, 995-1010.

[64] M. Søndergaard, E. Jeppesen, T.L. Lauridsen, Ch. Skov, E.H. van Nes, R. Roijackers, E. Lammens, R. Portielje, Lake restoration: successes, failures and long-term effects, Journal of Applied Ecology 44(2007) 6, 1095-1105.

[65] M. Beklioglu, O. Ince, I. Tuzun, Restoration of the eutrophic Lake Eymir, Turkey, by biomanipulation after a major external nutrient control I, Hydrobiologia 490(2003) 1-3, 93-105.

[66] J. Benndorf, Foodweb manipulation without nutrient control: A useful strategy in lake restoration?, Swiss Journal of Hydrology 49(1987) 2, 237248.

[67] M. Špoljar, T. Dražina , N. KuczyńskaKippen, Ch. Zhang, I. Ternjej, G. Kovačević, J. Lajtner, J. Fressl, Zooplankton traits in the water quality assessment and restoration of shallow lakes, Proceedings book of the $1^{\text {st }}$ International Conference „The Holistic Approach to Environment", ed. A. Štrkalj, Z. Glavaš, S. Kalambura, Association for promotion of holistic approach to environment, Sisak, Croatia, September 13 - 14, 2018, 697-702.

[68] J. Ejsmont-Karabin, Z. Gorelysheva, K. Kalinowska, T. Węgleńska, Role of zooplankton (Ciliata, Rotifera and Crustacea) in phosphorus removal from cycling: lakes of the river Jorka watershed (Masurian Lakeland, Poland), Polish Journal of Ecology 52(2004) 3, 275-284.

[69] N.K. Wickramasinghe, S.K. 
Yatigammana, Detection of suitable zooplankton from three taxonomic groups for application in biomanipulation, Ceylon Journal of Science 46(2017) 1, 27-35.

[70] R. Fernandez, S. Nandini, S.S.S. Sarma, A comparative study on the ability of tropical micro-crustaceans to feed and grow on cyanobacterial diets, Journal of Plankton Research 34(2012) 8, 719-731.

[71] K. Christoffersen, B. Riemann, A. Klysner, M. Søndergaard, Potential role of fish predation and natural populations of zooplankton in structuring a plankton community in eutrophic lake water, Limnology and Oceanography 38(1993) 3, 561-573.

[72] E. Jeppesen, P. Nõges, T.A. Davidson, J. Haberman, T. Nõges, K. Blank, T.L. Lauridsen, M. Søndergaard, C. Sayer, R. Laugaste, L.S. Johansson, R. Bjerring, S.L. Amsinck, Zooplankton as Indicators in Lakes: A Scientific-Based Plea for Including Zooplankton in the Ecological Quality Assessment of lakes according to the European Water Framework Directive (WFD), Hydrobiologia 676(2011) 1, 279-297.

[73] E. Jeppesen, M. Søndergaard, N. Mazzeo, M. Meerhoff, Ch.C. Branco, V.Huszar, F. Scasso, Restoration and Management of Tropical Eutrophic Lakes, ed. V. Reddy, Science Publishers, UK, 2005, 341-359.

[74] M. Špoljar, T. Dražina, J. Šargač, K. Borojević, P. Žutinić, Submerged macrophytes as a habitat for zooplankton development in two reservoirs of a flowthrough system (Papuk Nature Park, Croatia), Annales De Limnologie International Journal of Limnology, 48(2012) 2, 161-175.

[75] E. Jeppesen, J.P. Jensen, M. Søndergaard, T. Lauridsen, Trophic dynamics in turbid and clear water lakes with special emphasis on the role of zooplankton for water clarity, Hydrobiologia 408/409(1999), 217-231.

[76] B. Moss, R. Kornijow, G.J. Measey, The effects of nymphaeid (Nuphar lutea) density and predation by perch (Perca fluviatilis) on the zooplankton communities in a shallow lake, Freshwater Biology 39(1998) 4, 689697.

[77] N. Kuczyńska-Kippen, On body size and habitat selection in rotifers in a macrophye-dominated lake Budzyńskie, Poland, Aquatic Ecology 39(2005) 4, 447-454.

[78] S. Celewicz-Gołdyn, N. KuczyńskaKippen, Ecological value of macrophyte cover in creating habitat for microalgae (diatoms) and zooplankton (rotifers and crustaceans) in small field and forest water bodies, PLoS ONE 12(2017) 5, e0177317.

[79] T. Jurczak, A. Wojtal-Frankiewicz, P. Frankiewicz, Z. Kaczkowski, Z. Oleksińska, A. Bednarek, M. Zalewski, Comprehensive approach to restoring urban recreational reservoirs. Part 2 Use of zooplankton as indicators for the ecological quality assessment, Science of the Total Environment 653(2019), 16231640.

[80] J. Ejsmont-Karabin, The usefulness of zooplankton as lake ecosystem indicators: Rotifer Trophic State Index, Polish Journal of Ecology 60(2012) 2, 339-350.

[81] M. Špoljar, T. Tomljanović, I. Lalić, Eutrophication Impact on Zooplankton Community: A Shallow Lake Approach, The Holistic Approach to Environment 1(2011) 4, 131-142.

\section{Acknowledgements}

We would like to thank two anonymous reviewers who significantly improved the original manuscripts with their comments. We are also very grateful to Prof. Maria Špoljar (University of Zagreb) for all suggestions and $\mathrm{PhD}$ Łukasz Kruszewski (Institute of Geological Sciences PAS) who helped us with the English version of this paper and some comments. 